republics an integral part of the curriculum in primary and secondary schools. The latter is one of several basic studies on education in the other American republics planned as a part of a programme to promote better understanding of education in the Latin-American countries and to encourage closer educational co-operation.

The U.S. Office of Education does not limit its educational surveys to the American continent, but extends them to the wider field of what is known as comparative education. A good example is Leaflet No. 69 , which provides a clear and interesting report on "Education in China To-day". The report shows how, despite the invasion of her best developed educational centres, China is to-day demonstrating an unshakable confidence in public education. It seems quite obvious that the Central Office of Education in the United States is doing most valuable work which does not fall within the purview of any one of the forty-eight States.

\section{RESTORATION OF THE LENINGRAD INSTITUTE FOR PLANT CULTURE}

\section{BY IVAN BONDARENKO*}

$\mathrm{B}$ EFORE the War, the Leningrad Institute for Plant Culture had formed a valuable collection of seeds of many species of plants. When the siege of the city began, most of the scientific workers were evacuated into the interior of the U.S.S.R., but the seed collection had to be left behind at Leningrad. As soon as the city was freed, the workers returned.

Johann Eichfeld, who came back with a number of assistants, began re-sorting the collection; in the early spring he sent about ten thousand samples of various seeds to different parts of the Soviet Union with the request that they should be planted and a report on the growth furnished to the Institute. Telegrams have already been received reporting results from the Urals, North Caucasus, the Moscow region and Central Asia; in nearly all cases the results have been normal. This shows that, in the main, the collection has not been disturbed, and that with its help new research can be undertaken and the task of helping the restoration of regions devastated by the Germans can be tackled.

The Institute workers are now busy rebuilding their experimental station, which is situated three miles from Pavlovsk near Leningrad. This was formerly a big experimental farm where there were about two hundred varieties of fruits, three thousand varieties of berry fruits (including the only collection of gooseberries in the U.S.S.R.), about fifty thousand hybrid fruit trees and bushes, and many flowers and decorative plants. The station had cherries which ripen quickly in the short summer of this district, with some very fine varieties of strawberries, blackcurrants, plums and apples.

The German invaders destroyed the greenhouses, laboratories, seed stores, dwelling-houses and other buildings on the station. Many collections of plants were taken away to Germany, and those that were left were badly neglected. People from neighbouring villages and some ex-marines are now helping to rebuild the station.

Under the guidance of Profs. Fedor Teterev and Roman Cordon, houses are being rebuilt and implements repaired. The plantations of shrub fruits and

* Transcribed by $A$. Clifford. the orchards are being dug over. Seed is being prepared for rapid distribution. It is expected that in the autumn of 1944 and the spring of 1945 the Institute will provide farm nurseries with 100,000 strawberry cuttings, 50,000 young fruit trees, 60,000 currant bushes and many other plants. At the same time, rapid distribution of various plants is being organized so that by next summer some $3,000,000$ saplings and cuttings of fruit trees and bushes will be ready. Extensive plans for scientific research work are also being made.

\section{EARTHQUAKES DURING THE SECOND QUARTER OF 1944}

$\mathrm{D}^{\mathrm{t}}$ URING April and May, twenty-six strong earthquakes were registered by the instruments at Toledo (Spain), and ten by the seismographs at Wellington, New Zealand. In addition, twenty-five earthquakes were felt by people in some parts of New Zealand. During April 26-June 25, eight epicentres were determined from instrumental evidence by the United States Coast and Geodetic Survey in co-operation with Science Service and the Jesuit Seismological Association. On April 26 an earthquake originated at $1 \mathrm{~h} .53 \cdot 9 \mathrm{~m}$. G.M.T. from a provisional epicentre at $1^{\circ} \mathrm{S} ., 131^{\circ} \mathrm{E}$. , in western New Guinea. It was registered by the instruments at eleven United States observatories, and also at Toledo and Wellington. An after-shock from the same epicentre had its origin time at $14 \mathrm{~h} .37 .9 \mathrm{~m}$. G.M.T. on April 27. This was registered at Toledo and Wellington and was reported from fifteen other stations in the United States, Australia and the Pacific Islands.

The earthquake of May 6 originated at $0 \mathrm{~h} .13 \cdot 7 \mathrm{~m}$. G.M.T. from an epicentre at $22 \cdot 4^{\circ} \mathrm{N} ., 44 \cdot 8^{\circ} \mathrm{W}$, in mid-Atlantic. It was registered at nine American observatories and at Toledo, but not at Wellington, in any strength. The shock of May 25 at $1 \mathrm{~h} .06 \mathrm{~m} .39 \mathrm{~s}$. G.M.T. originated at $21 \cdot 5^{\circ} \mathrm{S} ., 179 \cdot 0^{\circ} \mathrm{W}$. in the Tonga Islands, with a depth of focus probably greater than $600 \mathrm{~km}$. It has been reported from sixteen observa. tories in the United States, Pacific Islands, New Zealand and Toledo. This earthquake was world shaking, and attained a maximum ground amplitude at Toledo of $45 \mu$. Also on May 25 there occurred another shock at $12 \mathrm{~h}$. $58 \cdot 1 \mathrm{~m}$. G.M.T. This time it was from an epicentre at $3^{\circ} \mathrm{S} ., 152^{\circ} \mathrm{E}$., in New Ireland. It was registered at fourteen stations in the United States, Pacific Islands, New Zealand and Toledo.

On June 16 an earthquake was registered at nine American observatories, and its epicentre as provisionally determined by the U.S. Coast and Geodetic Survey was at lat. $19^{\circ} \mathrm{N}$., long. $105^{\circ} \mathrm{W}$. Its origin time was $21 \mathrm{~h}$. $51 \cdot 5 \mathrm{~m}$. G.M.T. The shock of June 21 originated in the New Hebrides $\left(21 \cdot 5^{\circ} \mathrm{S} ., 169 \cdot 8^{\circ} \mathrm{E}\right.$.) at $10 \mathrm{~h} .58 \cdot 3 \mathrm{~m}$. G.M.T., and that of June 25 originated in mid-Atlantic ( $1^{\circ} \mathrm{S} ., 25^{\circ}$ W.) at $17 \mathrm{~h} .42 \cdot 2 \mathrm{~m}$. G.M.T. according to the determination based on reports from Fordham, Huancayo, San Juan and Spring Hill.

In New Zealand the strongest earthquakes to be felt had strength IV on the modified Mercalli scale. These were reported as follows: April 17 at Porangahau, April 22 at Blenheim, Cook Strait and Wellington, April 30 at Tolaga Bay, May 16 in the Takaka region and May 20 at Rotorua. On May 9 an earth tremor was felt at Wairoa and Napier with scale III, and some inhabitants of Napier again felt. a shock with scale III on May 31 . 